the nerves of those with high anxiety, and at subtly deflating those with egos beyond their accomplishments. He was calm, competent, and civilized.

In the days before e-mail and text messaging when people actually had to talk to one another, Morry was the go-to colleague for everything from professional interests and advice to consumer decisions. When you wanted the lowdown on what-to-buy or not-to-buy, Morry had researched the matter every which way. He was Consumer Reports without the subscription fee. This was not an easy matter in pre-Internet days. Of course, Morry's research on consumables, however thoroughly performed, was not always infallible. A colleague who had placed great faith in Morry's "consumer reports" and who was in the market for a car followed his seemingly authoritative advice every step of the way and purchased the car that Morry recommended. He came to conclude that it was the worst consumer mistake he had ever made. Morry probably would have drawn the conclusion that all expectations must be empirically tested.

Morry saw through pretense and malarkey more than most of us. He was skeptical of self-advertisers and catch phrases. He delighted in puncturing holes in PR flack and advertisingwhether in academia or the commercial world. He was fond of sending up the advertisement of a now long defunct, if improbably named, discount appliance store in Pittsburgh, Kelly and Cohen, which claimed that "we lose money on every sale but make up for it in volume." Morry was dedicated to the proposition that not only should we not fall for that line in our purchases but we also should be skeptical of its equivalents in politics.

Morry was both an intensely private person yet very sociable. He enjoyed interacting with colleagues, friends, and students. He never advertised his many merits or wished to have them advertised by others on his behalf. He was a throwback to the days before academic brag sheets came into style. Even in death, Morry wished to have no funeral or memorial services. The departmental colleagues, former students, and others from Pitt who had known Morry well during his career dutifully disobeyed his desire to have nothing said of him. Fortunately, two of Morry's colleagues at Pitt, Jon Hurwitz and Ronald Linden, thought it best to organize a remembrance event on April 28 that, like Morry himself, was full of kindness, humor, and dignity. One of Morry's nieces observed that he was "a modest man" who "would never toot his own horn." It was, none- theless, comforting to those of us who knew and appreciated him to toot it for him knowing full well that he would have disapproved.

Morry was predeceased by his wife, Eleanor. He leaves behind two nephews and two nieces and three grand-nephews and two grand-nieces. Contributions may be made in Morris Ogul's memory to the Dr. Morris S. \& Eleanor S. Ogul Fund c/o The University of Pittsburgh, Office of Institutional Advancement, 200 South Craig Street, 500 Craig Hall, Pittsburgh, PA 15260.

Bert A. Rockman
Purdue University

\section{James S. Pacy}

It is with great sadness that we report the death of James S. Pacy, professor emeritus of political science. Jim died at his home in Burlington, Vermont, on April 21, 2008, of complications from Alzheimer's disease at the age of 77 . Jim, of proud Hungarian descent, was born in Caledonia, Ontario, on August 17,1930 . His family emigrated to Manville, New Jersey, when he was two years old. Manville, at the time the company town of asbestos manufacturer Johns-Manville, was an ethnically diverse community just a short drive up from Princeton but in an entirely different world. His hometown was the topic of many a reminiscence and story told by Jim over the years. Manville, for Jim, was always a reminder of the importance of home, ethnic ties, and community. For him, that humble background would lead to greater things.

In 1952, Jim earned his undergraduate degree in history from Lebanon Valley College. He also earned an MA degree in history from the University of Missouri in 1956. But his love was political science and international relations, which culminated in his Ph.D. at American University in 1969, where he also received the Pitman Potter Medal in International Law. During his graduate years, he received a fellowship at Harvard University, where he studied under Prof. Hans Morgenthau of the University of Chicago, the leading scholar of realism in international relations.

Jim was a veteran of our armed services. From 1952-1956, he served in a variety of military capacities, especially at the U.S. Air Force "filter center" in Fargo, North Dakota. His chief assignment was to tour the region, training civilians in the identification of Soviet aircraft. Such was his prowess on the job that not a single Russian plane ever penetrated North Dakota airspace. More im- portantly, North Dakota was the home of his future wife, Ruth West Pacy. In 1956, after his discharge, Jim volunteered for service as an interpreter in processing Hungarian refugees at Camp Kilmer, New Jersey.

Starting in 1957, Jim worked in Washington, D.C., first at the National Federation of Wildlife, where he was co-editor of The Conservation Directory, then at the Special Operations Research Office (SORO) at American University, directed by the esteemed Prof. Harold Gosnell, one of the pioneering scholars of the Chicago school of behavioralism.

Through those years, Jim pursued his graduate studies while supporting his young family.

In 1965, Jim joined the faculty of Westminster College, in Fulton, Missouri, where his reputation as a skilled teacher quickly grew. Westminster was the site of Winston Churchill's famous "iron curtain" speech in 1946; for his part, Jim was a lifelong member of the Churchill Society. On a lark at an annual meeting of the APSA, Jim responded to a job posting by the University of Vermont. He met with two faculty members-professors Raul Hilberg, the noted Holocaust scholar, and Jay Gould-who urged his immediate hiring. From 1967 on, UVM would be his home until his retirement in 1993.

At UVM, Jim Pacy proved to be a hire of very great merit. As at Westminster, he quickly established a reputation as one of the best teachers on campus. His classes on international relations, diplomacy, and international organization were always in great demand. A small testament: his class on international organization was always over-subscribed and regularly filled the largest lecture halls on campus. In the summer of 1976, as the Montreal Olympics were underway, he offered his students a special treat: a course called "Politics and International Sports." Jim was beloved by his students, entertained them in his home, and kept in contact with many of them over the years. He served as the faculty adviser to the Warren R. Austin Model United Nations Club, as UVM's Foreign Service adviser, and as campus coordinator of the State Department's Diplomatin-Residence program. A strong supporter of the UVM men's hockey team and a season ticketholder, Jim served as chair of the university's Athletic Council and as faculty NCAA representative. In 1985, he was honored by UVM with the George V. Kidder Award. The Kidder Award is the highest faculty honor on campus, determined by distinguished service to the university by vote of the alumni association. 
His scholarly research mainly focused on diplomats and their activities, with publications in World Affairs, Foreign Service Journal, Eastern European Quarterly, Asian Affairs, Polish Review, Diplomacy, and Statecraft, as well as a number of contributions to a variety of edited volumes. Jim was also the coeditor, with Prof. Alan Wertheimer, of Perspectives on the Holocaust: Essays in Honor of Raul Hilberg. Perhaps his most important scholarly contribution was his co-authored study of diplomats of the Baltic "captive nations" with Prof. James T. McHugh: Diplomats Without a Country: Baltic Diplomacy, International Law, and the Cold War.

In his later years, Jim was a key participant in the Public Members Association of the Foreign Service, which advises the secretary of state on ambassadorial and other diplomatic appointments and promotions. He would rise to become vice president of the association and serve as a member of its board of directors. He also served on the council of consultants to the American Hungarian Foundation in New Brunswick, New Jersey.

Jim was a man of great wit, warmth, and humor, the latter often at his own expense. Jim was fond, for example, of telling new colleagues this story. Soon after his arrival at UVM, his parents visited. He told them he would be able to show them around only on Tuesday and Thursday, since he taught the other three days of the week. His mother gently patted his arm, and told him: "Don't worry Jimmy. No one back in Manville has to know that you only have a part-time job." However his work at UVM might be measured, it was a job and profession he loved and cherished.

In addition to Ruth, his beloved wife of 54 years, Jim is survived by their daughter Laura Echevarria of Atlanta, son Ben of Burlington, their spouses, and three grandchildren of whom he was extremely proud.

\section{John P. Burke Garrison Nelson Alan Wertheimer University of Vermont}

\section{David Rebovich}

On the morning of the day before he passed away David Rebovich felt under the weather. However, no flu (as he believed it to be) could prevent him from meeting his students to plan the next activity sponsored by the Institute of New Jersey Politics. Nor could it keep him from staying after the meeting to speak with those students who had need for his help or advice. One of the latter was a senior who decided to pursue the soughtafter position of intern at the governor's office. David agreed to recommend him for the position and the two parted. This however was not the last that the student heard of the position. Following David's funeral, the governor identified him and instructed him to submit the application.

I chose to begin these brief comments with the story of the last intern David had placed because it reveals, in a short concentrated way, some of the most essential attributes of David the person, the teacher, and the public intellectual. That just days before his death he had published an article criticizing the governor only serves to highlight the first of these characteristics: his tremendous influence. In the 23 years since his first public media appearance as a commentator on NJN's New Jersey Politics he had become "the undisputed dean of political observers in New Jersey" (state GOP chair Tom Wilson). This was not a question of quantity alone, though by the end of the century and until his premature death he averaged the astonishing number of some 600 media engagements in an academic year. Rather, it was the quality of his analysis that, to quote Democratic governor Jon Corzine, won universal acknowledgement as "nonpartisan, fair, and vital to the public discourse." His weekly columns appeared in the Trentonian, the Times of Trenton, the Philadelphia Inquirer, the New Jersey Lawyer, and, most recently, in Politics NJ. In 2001, the New Jersey chapter of the Society of Professional Journalists honored him as the best weekly columnist. No less and perhaps more profound was his impact as a commentator. As the most sought after source of insight by the media professionals and public at large, he explained in countless articles, radio, and television appearances the hidden reaches of the political world. It is little wonder, then, that Politics NJ named him among the (17 of 100) nonelected New Jerseyans "with clout, with impact on politics and government," or that he was identified among the most frequently quoted personalities in the state.

The unexpected ending of the story points to an additional attribute of David the person and the teacher. The rapidity with which his recommendation reached its destination (less than half a day in which he already felt unwell) could have been a result of some fortunate coincidence. However, for all who knew him, it was simply a reflection of the coalescence of the personal and the professional, his private life and his work. Boundaries between them become so blurred that his students and the people who populated the political world that he studied became his social group. He shared their lives, criticized them as he did himself, and rendered the problems they contended with his own. A member of the New Jersey Senate I spoke with in preparing these comments seized this up when he stated that it was this quality that accounted for his success as a public intellectual: "For him what others call work was a way of living, a habit of mind. He did not stand in relation to the political world as an outsider looking in and reporting what he saw."

This goes a long way to explaining David's unusual popularity as a teacher as well as the method of teaching for which he became famous at the university. In a small university such as Rider, we all are familiar with the "guru phenomenon." Students who find common language (and often enough garner good grades) keep on attending "their" professor's classes, so that each of us has a cadre of students who become familiar links among classes and come to know us better than most students do. What distinguished "Dr. Reb" (as his students called him) was that such a fellowship became a "club" in and of itself: a group of students and a teacher who met frequently and informally, so that class became the structured center of a vast informal network. Nights in residential colleges end late, and most students avoid 8:00 a.m. classes. Because interactions would usually continue after class and because David so frequently attended the late morning or early afternoon sessions and press conferences at the neighboring New Jersey Legislator, all his classes were conducted in the early mornings. All of them were filled to capacity, and were usually closed by the end of the first day of course registration. An early morning visit to Fine Arts Hall would force upon the caller their extraordinary nature: most classes were quiet, with the professor scribbling on the blackboard or engaged in monologues in half-empty rooms. David's packed classes were conducted as an ongoing dialogue among the students and between them and the professor, with frequent busts of laughter intercepting serious conversations.

Students do not learn only because committed professors tell them that their subject is of great consequence. David's total immersion in his subject and his students, coupled with his gifts as a teacher, made him successful in what, for lack of other words, could be called the marketing of his subject. What distinguished him was the ability to illustrate its relevance for his students' lives, an 